Binghamton University

The Open Repository @ Binghamton (The ORB)

The Society for Ancient Greek Philosophy Newsletter

$1-5-2004$

\title{
Aristotle and Theophrastus on the Emotions
}

William W. Fortenbaugh

Follow this and additional works at: https://orb.binghamton.edu/sagp

Part of the Ancient History, Greek and Roman through Late Antiquity Commons, Ancient Philosophy Commons, and the History of Philosophy Commons

\section{Recommended Citation}

Fortenbaugh, William W., "Aristotle and Theophrastus on the Emotions" (2004). The Society for Ancient Greek Philosophy Newsletter. 374.

https://orb.binghamton.edu/sagp/374

This Article is brought to you for free and open access by The Open Repository @ Binghamton (The ORB). It has been accepted for inclusion in The Society for Ancient Greek Philosophy Newsletter by an authorized administrator of The Open Repository @ Binghamton (The ORB). For more information, please contact ORB@binghamton.edu. 
This essay goes well beyond the few sections, V through VIII, that I submitted to the review committee of $S A G P$.

In conformity with my submission, my presentation will focus on V through VIII, though I will be pleased to respond to questions on any section of the paper.

\section{Aristotle and Theophrastus on the Emotions}

\section{W. W. Fortenbaugh}

The passions of men have long been a subject of great interest. Indeed, fascination with the subject can be traced back to the very beginnings of western literature: more precisely, to Homer's Iliad, whose opening line makes reference to the anger of Achilles. In Lattimore's translation, we read: "Sing, goddess, the anger of Peleus' son Achilleus." In the original Greek, the word translated by "anger," mênis, enjoys pride of place. Homer will tell a tale of angry passion, whose terrible consequences almost overwhelm the Achaean host. He will also tell how warriors become frightened when confronted by danger, how they respond to appeals for pity, and how they are overcome by laughter. ${ }^{1}$ This interest in emotional behavior is not peculiar to Homer. It is also clear in the writings of the lyric poets, tragedians, writers of comedy, historians, rhetoricians and philosophers. ${ }^{2}$ My concern will be with the last named, the philosophers, and in particular the early Peripatetics, who not only recognized the importance of emotional response but also subjected it to intense philosophic analysis. I plan to discuss this analysis, beginning with the late Platonic Academy, in which Aristotle played an active part. I shall move on to his independent views and take note of those of Theophrastus, Aristotle's pupil and successor as head of the Peripatos. I shall not hesitate to restate matters discussed on earlier occasions, ${ }^{3}$ for I want to offer an inclusive paper: one that both introduces a topic of great interest and at the same time takes note of its many aspects. However, I shall also be modifying earlier views, adding new analyses as well as illustrative material and replying to recent criticism. 4

\section{Emotions Distinguished from Other Passions}

In Plato's Philebus, a late dialogue concerned with pleasure, wisdom and human happiness, ${ }^{5}$ Socrates is made to draw a distinction between three kinds of mixed pleasures and pains. One kind is said to concern the body and to be found in the body itself. By way of illustration, Socrates cites the man who experiences a painful itch and finds pleasant relief in scratching (46A8-47C3). A second kind is said to

${ }^{1}$ For fright see, e.g., 3.30-7 and 22.136-7 (Paris is frightened of Menelaus, and Hector flees as Achilles approaches): for pity 22.59 and 24.516 (Priam's calls [vainly] on Hector for pity, and Achilles feels pity for the gray haired Priam); for laughter 2.270, cf. 1.599 (the Achaeans laugh at Thyrsites; cf. the gods laughing at Hephaestus).

2 There are innumerable examples; each person will have his own favorites. Here are some of mine: lyric, Anacreon 44 (the poet laments old age and expresses fear of death); tragedy, Euripides' Medea, passim (the eponymous heroine is so consumed by anger, that she ultimately kills her own children); comedy, Aristophanes' Clouds 1481-1509 (Strepsiades is so upset that he rejects a lawsuit in favor of burning down the Thinkery); history, Herodotus' Histories 7.35 (when Xerxes learned that a storm had broken up the bridge across the Hellespont, he had the Hellespont scourged with three hundred lashes); rhetoricians, Gorgias' Helen 15-19 (love is an excuse for bad behavior); philosophers, Plato's Republic 439E-440A (disgust fails to keep Leontius from running to view corpses lying beside the road).

${ }^{3}$ See the monograph Aristotle on Emotion, London: Duckworth and New York 1975 (reprint with epilogue 2002) and the articles cited in the notes to this chapter.

${ }^{4}$ I shall be modifying my view of the relation between Aristotle's rhetorical definition of emotion and his discussion of individual emotions (Sections II and III). In addition, I shall distinguish between different kinds of laughter (Section VI) and offer analyses in terms of similarity (Section VII) and difference in degree (Section VIII). Finally, I shall deal with recent criticism concerning good character and the goal of action (Section IX).

5 The Philebus is Plato's penultimate dialogue. Since his last work, the Laws, was left unfinished, we can say that the Philebus was Plato's last completed dialogue. Stylistic studies establish a close connection between the Philebus and the middle books of the Laws. That suggests contemporaneous composition. See L. Billig, "Clausulae and Platonic Chronology," The Journal of Philology 35 (1919) p. 233-4 and L. Brandwood, The Chronology of Plato's Dialogues (Cambridge: University Press 1990) p. 184, 206. 
involve body and soul. Socrates' example concerns replenishment. When a man is hungry and expects to be fed, then he feels the pain of an empty stomach and takes pleasure in the thought of being fed (47C3D4). A third kind is assigned to the soul independent of the body. It is illustrated by a list including anger, fear, longing, lament, love, emulation and envy, and by a lengthy discussion of the mixed feelings of envious individuals (47D5-50A9). Each of these three kinds of mixed pleasures and pains can be described as a passion - in Greek pathos ${ }^{6}$ - but as Socrates makes clear, they are very different. Bodily disturbances, scabies and other physiological abnormalities are fundamental to the first kind; normal bodily drives, hunger and thirst, are the basis of the second; and what we call emotions are the stuff of the third. For our purposes, the important point is that Socrates recognizes that emotions like anger and fear are neither diseased conditions of the body nor natural drives for replenishment. They are, of course, pleasant as well as painful, ${ }^{7}$ and for this reason they may be said to resemble the other two kinds of mixed pleasures and pains; but they are significantly different. As Socrates is made to say, they are "that mix which the soul alone often takes to itself" (47D8).

What Socrates finds difficult to explain is the relationship between thought and emotion; and as a consequence, he is unable to convince his interlocutor that pleasures and pains, fear and expectation can be correctly called true and false (36C6-D2). To be sure, Socrates is able to point out similarities between opinion on the one hand and pleasure and pain on the other, but he runs into trouble when he observes that pleasures often occur together "with" (meta) false opinion (37E10). The interlocutor construes the preposition "with" as simple concurrence and thinks of opinion as something external to pleasure: the opinion may be false, but no one would call the pleasure false (37E12-38A2). Socrates does not give up; he speaks of pleasure and pain "following" (hepesthai) true and false opinion (38B9) and then argues that pleasures and pains, including emotions like fear and anger, are sometimes based on (epi) reality and sometimes not (40D8-E4). When no objection is raised, Socrates asserts that true and false opinions "fill up" (anapimplanai) pleasures and pains with their own affection (42A7-9). To speak of "filling up" is to introduce metaphor. It expresses Socrates' belief that opinion and pleasures and pains are intimately connected, but it leaves unclear the precise nature of the connection.

In the Philebus, Socrates' difficulty is not resolved, but discussion was continued in Plato's Academy. The young Aristotle was a participant, and his early work, the Topics, ${ }^{8}$ provides some evidence concerning his contribution. I cite three passages. In Book 4, Aristotle discusses ways to attack an assigned genus. He recommends showing that a more or equally likely candidate is not the genus and illustrates his recommendation by reference to anger. Pain and the thought of being slighted are both parts of the essence of anger; but if the more likely candidate, pain, is not the genus, neither is the thought of being slighted (4.6 127b26-32). ${ }^{9}$ In Book 6, Aristotle takes up definitions in which the preposition "with" occurs. He recommends making clear how the preposition is used and illustrates the recommendation by reference to anger. When anger is defined as "pain with the thought of being slighted," the preposition means "on account of" (dia). It does not mean "and" or "made up out of" or "in the same receptacle" or "in the same place" or "in the same time" (6.13 150b27-151a19). As in the preceding example, the thought of being slighted is recognized as essential to anger, but now it is also explained as the cause of that emotion. Finally in Book 8, which is generally regarded as later than Books 4 and 6, a causal analysis appears to be accepted without question. ${ }^{10}$ Aristotle is discussing the use of coordinate terms in order to establish a premise; and by way of illustration, he introduces anger. If we want to establish that an angry man desires revenge on account of (dia) an apparent slight, then we

\footnotetext{
${ }^{6}$ See Philebus 46A10 and 47C2. In the first passage, pathe occurs; in the second, pathêmata. In both cases, the first kind of pathos is under discussion.

7 See Philebus 47D8, where Socrates quotes Homer's Iliad 18.108-9: "sweeter by far than dripping honey". Cf. Aristotle, Rhetoric 2.2 1378b5-7, where Homer's Iliad 18.109-10 is quoted.

${ }^{8}$ On the date(s) of the Topics, see J. Brunschwig, Aristote, Topiques. Paris: Budé 1967 p. lxiii-civ and J. Rist, The Mind of Aristotle: A Study in Philosophical Growth. Toronto: University of Toronto 1989 p. 283-5.

${ }^{9}$ I do not follow Brunschwig (above, n. 8) p. 109 in deleting oligôrias at 127b31. See Fortenbaugh, "On the Composition of Aristotle's Rhetoric: Arguing the Issue, Emotional Appeal, Persuasion through Character, and Characters Tied to Age and Fortune," in LHNAIKA. Festschrift für Carl Werner Müller, ed. Chr. MuellerGoldingen and K. Sier = Beiträge zur Altertumskunde (Stuttgart: Teubner 1997) p. 174 n. 30.

10 Book 8 may date to 343-0 B.C., when Aristotle was in Macedonia. See Rist (above, n. 8) p. 285. But whatever its precise date, it is probably a later part of the Topics, and the straightforward way in which the definition of anger is advanced may well reflect acceptance of the definition.
} 
should first win agreement concerning the definition of anger: i.e., that anger is a desire for revenge on account of (dia) an apparent slight (8.1 156a30-3).

Examples advanced in the Topics, need not represent a view endorsed by Aristotle; but in the case of anger, there seems little reason to doubt that the definition found in Book 8 represents Aristotle's considered opinion. It is in line with his remarks in Book 6 and exhibits striking similarities to the definition of anger set forth in the Rhetoric. There in Book 2, Aristotle defines anger as "a desire for revenge accompanied by pain on account of (dia) an apparent slight to oneself or to one's own, the slight being unjustified" (1378a30-2). This definition includes more than the definition of Topics 8-it includes a mention of pain and the qualifier "unjustified"11 - but in regard to anger being a desire for revenge on account of an apparent slight, it agrees fully with Topics 8. Aristotle, it seems, is now entirely clear about the involvement of thought in an emotion like anger. It is the cause of the emotional response; and as such, it is mentioned in the essential definition of the emotion in question.

Clarity concerning the involvement of thought in emotional response will have been achieved not only through a close examination of individual emotions but also through a general consideration of definition in the context of demonstrative science. I am thinking especially of the Posterior Analytics, in which Aristotle tells us that questions of essence ( $t i$ est $i$ ) and questions of cause (dia $t i$ ) are one and the same (2.2 90a15). His stock example is that of the lunar eclipse. The essential definition is one that not only speaks of a deprivation of light but also states the efficient cause: namely obstruction by the earth (90a16). Diminution of the moon's light resulting from any other cause may have the same appearance, but it is essentially different, for the lunar eclipse is by definition attributable to the interposition of the earth. ${ }^{12}$ The application to emotions is obvious, and Aristotle will not have missed it. He recognized the importance of thought as the cause of emotional response, and in the case of anger he offers a definition that mentions not only a final cause, revenge, but also an efficient cause, the appearance of being slighted (Rhetoric 2.2 1377a31-3).

In my preceding remarks, I have found it helpful to emphasize Aristotle's use of the preposition "on account of" (dia). To avoid any misunderstanding, I want to state clearly that Aristotle does not always use this preposition when referring to the efficient cause; and that is true both of the Posterior Analytics and of the Rhetoric. In the former work, we find him substituting "by" (hypo): e.g., to the question what is an eclipse, he replies "a deprivation of light from the moon by the obstruction of the earth" (2.2 90a156). ${ }^{13}$ In the latter, prepositions like "resulting from" $(e k)$ or "concerning" (peri) are found: e.g., fear is defined as "a pain or disturbance resulting from the appearance of a future evil which is destructive or painful" (2.1382a21-2), and shame as "a pain or disturbance concerning those evils which appear to contribute to bad reputation" $(2.61383 \mathrm{~b} 12-13)$. There is no confusion here. In the early stages of an investigation, it is often useful to avoid variation in terminology; but once clarity is achieved, consistency in the use of single words and phrases becomes unimportant and perhaps misleading. For the student may fail to appreciate the many different ways in which the same notion is expressed in every day language.

\section{A Rhetorical Definition of Emotion}

In Rhetoric 2, prior to the discussion of individual emotions like anger and fear, Aristotle offers a general definition of the emotions. It runs as follows: "The emotions are all those feelings on account of which men so change as to differ in judgment, and which are followed by pain and pleasure" (2.1 1378a20-2). By way of clarification, Aristotle adds a short list of emotions: "for example, anger, pity, fear and all other such emotions and their opposites (1378a22-3). The reference to opposites is clear enough. Aristotle is looking forward to the subsequent treatment of individual emotions, in which opposites are discussed together: e.g., anger is paired with calmness (2.2-3), pity with indignation (2.8-9) and fear with confidence (2.5). More important is the list of particular emotions. For without this list, the definition might be taken inclusively, so that it covers diseases and bodily drives. For these passions, at least in some forms, not only involve pain and pleasure but also affect a man's judgment.

11 The qualifier "unjustified" emphasizes the evaluation involved in anger. See Section IX ad init.

12 See Post. Anal. 2.8 93b5-6 where rotation of the moon and extinction are mentioned as possible causes that are ruled out by an essential definition that includes the cause.

${ }^{13}$ In On Soul 1.1 403a27, hypo occurs in the definition of anger. See Section V, where the definition is quoted. 
A different way to eliminate diseases and bodily drives from consideration would be to include within the definition a reference to thought as the efficient cause. If the argument of the preceding section is correct, Aristotle was capable of giving such a definition, but he chose not to do so. Instead he refers to change of judgment as a consequence of emotions like anger, pity and fear. That almost certainly reflects Aristotle's concern with rhetoric and more precisely his interest in the power of emotional appeal. The orator who cannot persuade his listeners by arguing the issue may try to effect a change in judgment by working on their emotions. In another context, that effect might be ignored or dismissed as a consequence of emotional response and not an essential feature. But in the context of rhetoric, Aristotle makes it a defining mark, for he is interested in a particular group of emotions: namely those strong emotions that orators arouse when argument fails. Weak emotions that do not affect the critical capacity of the audience are of no use and therefore excluded by defining emotions in terms of altered judgment.

So much is clear. But there are problems with the definition of emotion within the context of Aristotle's Rhetoric. One problem concerns altered judgment. Introducing the discussion of emotional appeal and prior to the general definition of emotion, Aristotle speaks of preparing a judge by putting him into an emotional condition. For things do not appear the same to persons who feel friendly and feel hate, and to persons who are angered and are calm. They appear either altogether different or different in degree (2.1 1377b24, 28-9, 31-1378a1). Aristotle's words are clear enough, and they explain the inclusion of friendliness and hate (philia and misos) within a discussion of emotional appeal (2.4). Nevertheless, it is not clear that persons who feel friendly and hate are always affected in regard to judgment. It may be that emotions like anger and pity normally (though perhaps not always) distort a person's critical faculty, so that it is no better than a warped straight stick (cf. 1.1 1354a24-6), but friendliness and hate are much less closely tied to distorted judgment. Hate, which is said to be free of pain (2.4 1382a12-13), seems the appropriate emotion for a juror who votes on the basis of the evidence to condemn a hardened criminal. And friendliness in the sense of goodwill (eunoia) may be thought desirable in a juror, providing it is exhibited equally in regard to both plaintiff and defendant. ${ }^{14}$ In addition, the orator seeks to present himself as a man of goodwill: a friend of the city (philopolis) 15 and someone well disposed toward his audience $(2.11377 \mathrm{~b} 26-7,1378 \mathrm{a} 8)$. Aristotle tells us that goodwill and feelings of friendship will be discussed among the emotions $(2.11378 \mathrm{a} 18-19)$, but he certainly does not want to say that manifesting goodwill is tantamount to an announcement of biased judgment. That may explain in part why there is no account of goodwill in the subsequent discussion of individual emotions, but I doubt that it is the whole story or even the most important factor. My guess is that the account of individual emotions (2.2-11) was transferred to the Rhetoric from a different context, probably from a lost work like Divisions or On Emotions, Anger; 16 and that the account never included a discussion of goodwill distinct from that of feelings of friendship. But whatever the truth concerning the origin of the account of individual emotions, it seems clear that Aristotle's introductory remarks on preparing a judge emotionally so that things appear to him in a certain way $(1377 \mathrm{~b} 24,30-1378 \mathrm{a} 6)$ are in line with the subsequent definition of emotions as feelings that cause a change in judgment (1378a6). Together they rule out those cases of friendliness and hate which are not relevant to emotional appeal: i.e., those that are of no help when the orator seeks to make the weaker argument appear the stronger.

\section{III. "Which Are Followed by Pain and Pleasure"}

Another problem with the definition of the emotions concerns the phrase "which are followed by pain and pleasure" (1378a21-2). Should we understand this phrase to mean that whatever counts as an emotion is necessarily both painful and pleasant? ${ }^{17}$ A positive answer is encouraged by Plato's

${ }^{14} \mathrm{Cf}$. Isocrates, Antidosis 22, where the Athenians are criticized for not exhibiting common goodwill to competing parties. Earlier in section 21, Isocrates refers to the oath that bound jurors to listen "equally." Apparently common goodwill is thought of as a guarantee of impartiality.

15 Cf. Thucydides, Histories 2.60.5 (Pericles on himself) and Plato, Apology 24B (Socrates ironically of Meletus).

${ }^{16}$ See G. Kennedy, Aristotle on Rhetoric: A Theory of Civic Discourse (Oxford: University Press 1991) p. 122 and Fortenbaugh, "On the Composition" (above, n. 9) p. 173-80.

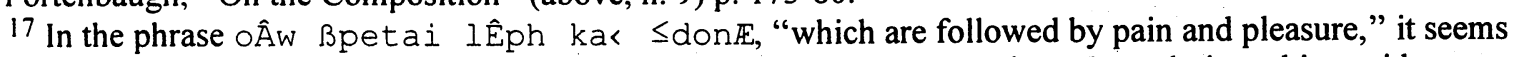
natural to construe $\beta p e t a i$ as a logical term indicating an essential connection. Not only is nothing said to suggest 
Philebus, for there Socrates is made to speak of three kinds of mixed pleasures and pains. The third kind is illustrated by a list of standard emotions - anger, fear, yearning, mourning, love, emulation and envy (47E1-2) - and then elucidated by a brief discussion of anger, lament, yearning, weeping at tragedies and the mixed feelings of envious individuals (47E5-50B6). Since Aristotle's thoughts on emotion almost certainly take their start from the Philebus, we might expect him to make the involvement of both pain and pleasure a defining mark of emotional response. But this expectation runs into difficulties in Aristotle's treatment of the individual emotions. None of the definitions mentions pleasure, and one emotion, namely hate (misos), is explicitly dissociated from pain. Introducing a contrast with anger, Aristotle tells us that the angry man feels pain, but the man who hates does not (2.4 1382a12-13). The contrast is intelligible. Angry men are responding to personal insult and as a result feel pain. Men who hate are not so affected, for they are not responding to a personal attack. Rather, their emotion is aroused by the odious qualities of persons with whom they may have no contact whatsoever. But if such a contrast is intelligible, it fits poorly with the idea that emotions are accompanied by both pain and pleasure. Should we, then, construe the phrase "which are followed by pain and pleasure" in terms of "and/or"? Aristotle is not requiring that both pain and pleasure be involved in emotional response; it is sufficient that one or the other be present. That may well be correct, but it should be noted that the discussion of hate makes no reference to pleasure, so that we may wonder whether hate qualifies as an emotion on the "and/or" interpretation. $18 \mathrm{We}$ can, of course, introduce pleasure: i.e., we can say that the man who feels hate takes pleasure whenever he thinks of the hated person ceasing to exist (cf. 1382a15), but the idea is not spelled out or even clearly suggested in Aristotle's discussion of hate. ${ }^{19}$

The definition and discussion of kindness (charis) in Rhetoric 2.7 raise similar worries. Aristotle defines kindness as altruistic service to someone in need (1385a18-19), 20 and in the discussion that follows, he focuses on the needs of the person served (1385a20-34) and the fact that the service must be rendered freely and without consideration of personal gain (1385a34-b10). What is missing is any reference to the pain or pleasure felt by the person rendering kindness. There is, of course, mention of the pain felt by the person in need $(1358 \mathrm{a} 23,25,33)$, but that only serves to emphasize Aristotle's silence concerning any painful or pleasurable feelings felt by the person who does good service. Silence here may exhibit good judgment, for it is not at all clear that meeting the needs of another (i.e., acts of kindness) must be accompanied by any feelings whatsoever. A man may simply think it right and proper to be helpful and therefore stand by others who are in need. ${ }^{21}$ But having said that, I want to suggest that such a view of kindness may not be Aristotle's view. For in Rhetoric 1.11, Aristotle discusses pleasure and states clearly that conferring a benefit (eu poiein) is pleasant. It implies possession and superiority, both of which people desire (1371a34-b4). The pleasure here is one of self-satisfaction and not dissimilar to that felt by the man who laughs because he thinks himself superior to another. ${ }^{22}$ It may also be compared with Malcolm Heath's explanation of Aristotelian tragic pleasure. The virtuous spectator is pleased with himself, knowing that he responds correctly to the action of the tragedy. ${ }^{23}$ Only in the case

otherwise, but also the deductive method that characterizes Aristotle's treatment of the individual emotions suggests such an interpretation. For Bpesyai as a logical term, see Prior Analytics 1.27 43b1-38, and for Aristotle's deductive method in analyzing the emotions, see Fortenbaugh, "Aristotle's Rhetoric on Emotions", Archiv für die Geschichte der Philosophie 52 (1970) p. 51-3 and Aristotle on Emotion (above, n. 3) p. 16.

18 There is no definition of hate, so that we cannot say with certainty whether an Aristotelian definition of hate would have mentioned pleasure. However, since none of the definitions put forth in the Rhetoric mention pleasure, it seems unlikely that pleasure would have been mentioned in a definition of hate, were it included in the Rhetoric.

${ }^{19}$ See 2.4 1382a15: the man who hates wishes that the object of his hate cease to exist. But since the man who hates is not pained by the object of his hate, will he be pleased by the object's non-existence? We cannot apply the general principle that anyone who is pained by the existence of a thing is necessarily pleased by its non-existence (2.9 1387a1-3), for the man who hates is not pained.

${ }^{20}$ Kindness is defined as "service to one in need, not in return for something, nor in order that something may be gained by the person rendering the service, but rather by that person (who is in need)."

${ }^{21}$ It may be significant that the account of kindness emphasizes action. The emotion is defined as a service (hypourgia 1385a18) and the subsequent discussion refers to people who render service (1385a19), stand by (paristasthai 1385a26) and help (hypêretein 1385a26-7). For Aristotle, it seems, action is central to kindness, and feelings of pain and pleasure are either irrelevant or of lesser importance. As the immediately following remarks make clear, I prefer the latter alternative.

22 I return to laughter in Sections IV, V and VI.

${ }^{23}$ M. Heath, "Aristotle and the Pleasures of Tragedy," in Making Sense of Aristotle: Essays in Poetics (London: Duckworth 2001) p. 16-20. 
of kindness, as presented in Rhetoric 2.7, virtue is not a requirement. All men desire possessions and superiority, and when acts of kindness make them conscious of possession and superiority, they feel pleasure. Perhaps, then, kindness can be viewed as a pleasant emotion: a man becomes aware of someone in need, responds by providing assistance and takes pleasure in doing so. That kindness also involves pain is nowhere stated, but the idea is not foolish. Aristotle tells us that acts of kindness are directed toward someone in need (1385a18), and that such acts are not motivated by selfish interests (1385a18-19, 1385b1). That suggests concern for the person in distress - a concern that is likely to be painful in varying degrees. This is, of course, speculation, but it may not be unreasonable speculation.

There is a further difficulty with Rhetoric 2.7 that should not be passed over without at least brief mention. I am thinking of the opening lines of the chapter, for here Aristotle asks three questions about being grateful (charin echein) and not about kindness. He asks, "Toward whom do men feel grateful and on what grounds and how are they disposed?" (1385a16-17). And later in the chapter, he says that the opening questions have been answered and that it is now clear what sources must be drawn upon (1385a29-31). That suggests that the primary focus of the chapter is gratitude, and that kindness is defined only because it is important as the grounds that underlie feelings of gratitude. ${ }^{24}$ But if that is correct and Aristotle's primary concern in Rhetoric 2.7 is gratitude, then we are left wondering why he fails to offer a definition of feeling grateful and to argue deductively on the basis of this definition. 25 This is how he treats other emotions like anger and fear (which I discuss next) and we might expect him to discuss gratitude in the same way. Furthermore, when he concludes his discussion and turns to pity, he says that he has now spoken about doing a kindness and not being kind, i.e., obliging and disobliging (charizesthai kai acharistein, $2.81385 \mathrm{~b} 10-11){ }^{26}$ He does not say that he has spoken about being grateful. I leave the matter undecided and observe only that the chapter is less than perspicuous, perhaps because something has fallen out, or the chapter was not originally written for the Rhetoric, or both.

Whatever the truth concerning kindness and gratitude, I want to suggest that several of the emotions discussed by Aristotle may be said confidently to involve both pain and pleasure. One such emotion is anger, which comes first in Plato's list of mixed pleasures and pains (Philebus 47E1). Although the Aristotelian definition of the emotion mentions only pain (1378a31), the analysis that follows immediately introduces pleasure. We are told that all cases of anger are accompanied by the pleasure that derives from the expectation of revenge (1378b1-2). Just as Socrates had done in the Philebus (47E9), so Aristotle in the Rhetoric cites Homer's Iliad 18.109, where anger is said to be sweeter than honey $(1378 \mathrm{~b} 5-7)$, and in connection with this Homeric passage, Aristotle tells us that no one feels anger when there is no prospect of taking revenge (1.11 1370b10-13, cf. $2.11378 \mathrm{~b} 3-5)$. Anger, then, is a practical emotion, 27 and as such it involves a goal (i.e., revenge) that provides pleasure to the extent that it appears obtainable.

Another practical emotion is fear, which is mentioned second in the Philebus (47E1). ${ }^{28}$ In this case, we may be tempted to rule out an analysis comparable to that of anger. ${ }^{29}$ For not only does the definition of fear fail to mention pleasure (it mentions only pain, $2.51382 \mathrm{a} 21$ ), but also the subsequent discussion of fear makes no mention of pleasure. The absence of any mention of pleasure in the definition is relatively unimportant, for the same is true of the definition of anger and all the other definitions given in the Rhetoric. More impressive is the subsequent discussion. For unlike the discussion of anger, which almost immediately makes reference to pleasure (some three or four lines after the definition, 2.2 $1378 \mathrm{~b} 2$ ), the discussion of fear is silent concerning pleasure. At first reading, that may seem decisive, but there are grounds for hesitation. In particular, the discussions of individual emotions are in some cases incomplete (kindness may be an example; emulation will be discussed in the next paragraph), and in the case of fear, it is easy to supply what is needed to develop an analysis comparable to that of anger. For in the chapter on fear, Aristotle tells us that some hope or expectation (elpis 1383a5) of safety must be

${ }^{24}$ See the epilogue in Aristotle on Emotion (above, n. 3) p. 107-8. We await a fuller treatment by David Konstan (2004?).

25 On Aristotle's deductive method in the Rhetoric, see the literature cited above in note 17.

${ }^{26}$ Charizesthai at $2.71385 \mathrm{~b} 10$ is the middle infinitive. It may be compared with kecharismenoi at 1385a27-8 and chariountai at $1.61363 \mathrm{a} 33 \mathrm{Cf}$. also Nicomachean Ethics $5.51133 \mathrm{a} 5$, Politics $2.51263 \mathrm{~b} 5$ and other passages cited by Bonitz s.v. charizesthai. For charizesthai and acharistein together, see Plato's Symposium 186C3-4

27 On "practical" emotions, see Aristotle on Emotion (above, n. 3) p. 79-83.

28 At Philebus 50C11-D1, the mixture of pain and pleasure in fear is reaffirmed.

${ }^{29}$ See Heath (above, n. 23) p. 8, 17, who denies that the accounts of anger and fear are comparable. 
present. A sign of this, he suggests, is the fact that fear makes men deliberate, and no one deliberates about what is hopeless (1383a5-8). Unless I misunderstand Aristotle, the expectation of safety is pleasant in the same way that the expectation (elpis 1378b2) of revenge is pleasant to an angry individual. We may turn again to the discussion of pleasure in Rhetoric 1.11. There Aristotle tells us that it is pleasant to expect things that are pleasant when present, i.e., to expect things that bring delight or great benefit. Aristotle asserts this as a general rule (1370b7-11) and then illustrates the rule by reference to anger. He cites Homer (anger is sweeter than honey) and tells us that we do not feel anger toward someone on whom revenge is thought to be impossible (1370b10-14). ${ }^{30}$ In Rhetoric 1.11, Aristotle does not apply the general rule to fear, but we can do the work for him. Fear is pleasant to the extent that there is present some expectation or hope of safety - a great benefit (1370b8) - for which a frightened man deliberates $(1383 \mathrm{a} 5-8)$. When there is no hope of safety, there is no pleasure, no deliberation and in fact no fear. 31 The case of anger is comparable: the expectation or hope of revenge is not only pleasant but also necessary to the occurrence of the emotion.

Still another practical emotion is emulation (zêlos). Aristotle defines this emotion as a pain caused by the presence, in persons like ourselves, of good things that are highly valued and that we ourselves can obtain (2.11 1388a30-3). Here there is mention of pain but not of pleasure. Similarly the subsequent discussion considers the goods and persons who arouse emulation but has nothing to say about the pleasure that may be involved in emulation. We are, however, told that the person who experiences emulation take steps to acquire the goods that arouse his emotion (1388a35), that the goods are considered obtainable $(1388 \mathrm{~b} 1-2)$ and that the goods include virtue and all those things that benefit other people (1388b10-12). Perhaps, then, we can say that the emulous person does feel pleasure to the extent that he expects to obtain certain kinds of goods. While taking steps to acquire virtue, he enjoys the prospect of being honored for his virtue $(1388 \mathrm{~b} 10-11,13)$, and while pursuing goods that are useful and serviceable to others he is pleased not only by the prospect of being honored $(1388 \mathrm{~b} 11-12)$ but also by thoughts of possession and superiority (1.11 1371a34-b4). ${ }^{32}$ All this is, of course, speculation, but it seems to me sound speculation that Aristotle would accept. What he would not accept is criticism for failing to offer complete accounts of the several individual emotions. Like a good orator, a good lecturer leaves unsaid things that the listener can supply for himself. 33

\section{Dispositional Emotions and Other Dispositions}

In the preceding section, I discussed the fact that Aristotle withholds pain from hate (misos) and nowhere mentions pleasure within the discussion of that emotion. That was seen to create a difficulty in regard to the general definition of the emotions, for that definition mentions both pain and pleasure (2.1 1378a20-2). To explain the difficulty, it might be suggested that Aristotle thinks of hate as a dispositional emotion. The idea is not foolish, for lacking pain and pleasure is a mark of dispositional emotions: when an occurrent emotion becomes dispositional, feelings of pain and pleasure typically subside and remain latent until they resurface in a new episode. Moreover, the relevant chapter of the Rhetoric contains no definition of hate, so that we seem free to conceive of hate in whatever way best fits Aristotle's discussion of the emotion. ${ }^{34}$ Nevertheless, interpreting hate as a dispositional emotion

30 I do not apologize for rendering phainomenôi (1370b13) with "is thought to be." See Aristotle on Emotion (above, note 3) epilogue p. 96-103.

31 For fear to occur there must be some hope of safety (see Rhetoric 2.5 1383a5-6 already mentioned above). Hence, where there is no hope of safety, there is no fear. There may be some other emotion like feeling dejected: but that would not be fear.

32 See above, this section, on kindness.

33 Cf. Demetrius Rhetor, On Style 222 citing Theophrastus = no. 696 FHS\&G.

34 Failure to define hate (see the preceding section with $n$. 18) does not make the discussion of this emotion unique, for lack of a definition is also true of being unkind (acharistein $2.81385 \mathrm{bl} 1$ ) and feeling contempt (kataphronein 2.11 1388b22-8). Moreover, hate is discussed second in its pair: it comes after feeling friendly and can be understood as the opposite of that emotion. Indeed, Aristotle recommends studying hate from its opposite (2.4 1382a 1), so that formulating a proper definition may have been passed over as unnecessary (cf. phaneron 1382a1). The same may be said of feeling contempt. It is said to be the opposite of emulation (2.11 $1388 \mathrm{~b} 22-4)$, so that a full discussion with definition will have seemed unnecessary. Not very different is the treatment of shamelessness (anaischuntia), which is conceived of as the opposite of shame. Although the beginning of the account of shame includes what may count as a definition of shamelessness (2.6 1383b15-17), there is no 
introduces a new difficulty. The discussion of the emotions in Rhetoric 2 is presented as a discussion of occurrent emotions - what an orator arouses in the course of and especially at the end of a speech and hate is nowhere referred to as an exception. 35 Rather, it is mentioned at the very start of the discussion of emotions as if it were paradeigmatic $(2.11377 \mathrm{~b} 32)$, and it is presented as the opposite of feeling friendly (philia), which is associated with both pleasure and pain (2.4 1381a4-8). Unless we embrace the idea that the discussion of the individual emotions was not written for the place it now occupies in Rhetoric 2 (as I am inclined to $\mathrm{do}^{36}$ ), then, we have little choice but to view hate as an occurrent emotion.

We should, however, be clear that Aristotle does connect hate with a disposition of a different kind. In a political-ethical context, he follows Plato (Laws 2 653B1-C4, 660A3) and explains moral education in terms of liking and hating. Young people are habituated to be delighted and to hate correctly (chairein and misein, Nicomachean Ethics 10.9 1179b25-6; chairein-philein and misein, Politics 8.5 1340a15). They acquire virtuous dispositions that Aristotle speaks of as êthê. To be sure, these êthê or kinds of character are related to emotional response, but in themselves they are neither occurrent nor dispositional emotions. Occurrent emotions are responses to particular situations and as such are directed toward individuals or a particular group of individuals. 37 Similarly, dispositional emotions have individuals or particular groups as their object. That is not true of the dispositions that are instilled during moral education. A young person is habituated to view unjustified slights as wrong and to evaluate negatively all forms of vice. Confronted by someone who is insulting or vicious, he will experience anger or hate, but until such a circumstance occurs, his condition is not that of an occurrent emotion or one that has become dispositional. Rather he is properly disposed in regard to anger and hate. ${ }^{38} \mathrm{I}$ return to this topic in Section IX.

It may be helpful to call attention to two other ways in which men are disposed to emotional response. First, emotions are natural to human beings, so that men are likely to experience, e.g., anger when slighted and fear when threatened. Such a natural disposition does not guarantee a morally correct response or indeed any response at all. Some people have a weak capacity for emotional response, so that they occasionally, perhaps often, fail to respond to situations that normally excite a response. Second, (and this is what interests me) an occurrent emotion of one kind may predispose a man to experience an emotion of a different kind. For example, if a man is feeling anxious about some future situation and another person treats his anxiety as unimportant, he is likely to become angry and to lash out at that person. An Aristotelian example is the man involved in war. He is anxious concerning his safety, feels frightened and is easily angered by another who regards the war as unimportant $(2.21379 \mathrm{a} 18-20)$. As Aristotle puts it, the emotion that presently controls him prepares the way (proodopoieisthai) for anger $(1379 \mathrm{a} 21-2)$. That does not mean that fear and anger become a single emotion. They are two different emotions, though the one predisposes a person to experience the other. Moreover, the anxiety or fear that comes with being at war does no more than open the door to anger. It is not sufficient in itself to cause anger. Indeed, it also opens the door to other emotions. Confronted by dangers and feeling frightened, a man feels gratitude, not anger, toward another who stands beside him and joins the fray on his behalf $(2.7$ 1385a24-5).

proper treatment of shamelessness. Once the discussion of shame is completed, Aristotle dismisses shamelessness, telling us that we shall have all we need from its opposites (1385a14-15).

35 Cf. S. Leighton, "Aristotle and the Emotions," Phronesis 27 (1982) p. 170 n. 14.

${ }^{36}$ Nothing is said within the discussion of hate $(2.41381 \mathrm{~b} 37-1382 \mathrm{a} 15)$ that proves or disproves that the discussion was written for its present position within the Rhetoric. However, the concluding remarks concerning friendliness as well as hate (1382a16-19) are tied to rhetoric (demonstrating that certain people are enemies or friends, refuting claims to be one or the other, attributing a disputed action to either anger or hate) and might be thought to establish a close connection with the Rhetoric. Nevertheless, these concluding remarks, occurring as they do at the end of the discussion, may be late additions. Cf. the concluding remarks to the discussions of anger (2.2 $1380 \mathrm{a} 2-4)$ and envy (2.10 1388a25-8). Indeed, such appended remarks may be thought to tell in favor of an original context different from the present position within the Rhetoric.

37 Here I use "individuals" inclusively to cover things as well as people. An approaching rocket as well as an enemy soldier may cause fear. Aristotle aside, I do not rule out that a person may respond emotionally to a general idea (e.g., the thought of sin or moral goodness), but such a response is not under consideration in Rhetoric 2.

38 For completeness' sake, I add that occurrent emotional response may be part of moral training. Young people are exposed to particular situations and rewarded or praised when they respond in a way that is morally correct. Over time they become habituated to respond correctly on all occasions. I.e., they acquire a disposition that relates directly to emotional response but is not in itself an occurrent emotional response. 
That may be obvious, but it may be overlooked when one speaks of the pleasures and pains involved in emotional response. As an example, I choose envy (phthonos), which is listed last in the Philebus $(47 \mathrm{E} 2$, cf. $50 \mathrm{C1})$. It is said to be full of pleasures (47E5) and discussed at some length. First Socrates describes envy as pain of the soul (48B8-9), after which he speaks of the man who experiences envy and takes pleasure in the misfortunes of his neighbor (48B11-12). Finally he describes envy as a mix (meixis) of pleasure and pain (49A8-9) and says that envy is a kind of unjust pleasure and pain (49D1). The grounds that underlie the mixture are clear: the goods possessed by a neighbor cause pain, 39 and the misfortunes of the same neighbor arouse pleasure. What gives pause is the notion of mixture. Are both pain and pleasure essentially involved in envy? What Socrates goes on to say fails to answer the question clearly. First, he speaks of envy effecting (apergazesthai) pleasure in the evils that befall friends (50A23 ). That may be compatible with viewing envy as a predisposition to certain feelings of pleasure. Much as anxiety makes a man prone to anger and yet is not to be confused with anger, so envy might be regarded as a condition that makes a man liable to feel certain pleasures but remains distinct from those pleasures. Nevertheless, Socrates continues to speak of a mix and says that the pleasure is felt at the same time (hama) as the pain (50A6-8, B4). Without some comment to the contrary, Socrates seems to be saying that both pleasure and pain are essential ingredients in envy.

Aristotle does not address the problem directly, but his treatment of envy in the Rhetoric is instructive. He defines the emotion as a certain pain based on the apparent successes of people like ourselves (2.10 1387b22-3). He explains that the envious man is not motivated to obtain something for himself; rather, he is pained by what others have $(1387 \mathrm{~b} 23-4)$. Various kinds of people who experience the pain of envy are listed: e.g., ambitious people, those who profess wisdom, rivals in sport, old men in relation to young men (1387b25-1388a23). In conclusion, Aristotle tells us that envious people take pleasure in things opposite to those that cause pain (1388a23-5). He does not offer examples, but it is clear that he means failures and generally whatever humbles people like ourselves. Aristotle's use of chairein, "to be delighted" (1388a23) may recall similar usage in the Philebus (49D7). In any case, the problem remains the same. Are these pleasures part of envy or are they distinct from envy? If we read on in the Rhetoric, we find within the discussion of emulation a helpful comparison. Aristotle tells us that the man moved by emulation takes steps to obtain good things, while the man moved by envy takes steps to prevent his neighbor from having them (2.11 1387b23-4). If I understand Aristotle correctly, he is suggesting that not only emulation but also envy may be viewed as a practical emotion. Both involve goals that lead to action. That is not my conception of envy: I am prepared to speak of envy when a man does nothing but sulk. ${ }^{40}$ But if it is Aristotle's, then the pleasures of envy can be divided in two. Like the angry man who is pleased when he expects to obtain revenge $(1.111370 \mathrm{~b} 32)$, the envious man may experience pleasure when he imagines his neighbor falling on hard times. Such pleasure can be viewed as an ingredient in envy. However, the pleasure that occurs when the neighbor actually falls on hard times is a different matter. That pleasure replaces the pain of envy and is likely to manifest itself in an overt response like laughter. In the Philebus, laughter (gelan, 49E9, 50A5, 8) and the ludicrous (geloion, 48C4, 49B8, C4, E2) are tied to envy (48C4), and in the Poetics, Aristotle connects comedy with inferior character (2 1448a17-18, 5 1449a32-3). He seems to endorse a superiority theory of laughter. ${ }^{41}$ But whatever the truth concerning comedy, laughter is not tied to envy, except in so far as envy predisposes a man to laugh at a neighbor's failure. ${ }^{42}$ It is similar to anxiety, which predisposes a man to become angry if slighted, but is not in itself essential to anger.

\section{Emotions and the Body}

\footnotetext{
39 The grounds for experiencing the pain of envy are not stated explicitly, but they are clearly the opposite of what excites pleasure in the envious individual.

40 In fairness to Aristotle, it should be noted that he never says explicitly that envy is incompatible with inaction. But the parallel treatment with emulation $(2.111387 \mathrm{~b} 23-4)$ combined with the statement that envy is not felt toward people who are greatly superior $(2.101388 \mathrm{a} 11-12)$ suggests that envy is conceived of as a practical
emotion.

41 See Aristotle on Emotion (above, n. 3) p. 20 and below Section VI.

42 Laughter has a variety of causes (see Section VI). Indeed, envy is not necessary for the occurrence of laughter even when the fundamental cause of laughter is a recognition of one's own superiority. Aristotle tells us that we do not envy people who are far superior (Rhetoric 2.101388 al1-12), but should such a person suddenly be humbled, we might be delighted and express our feeling in laughter.
} 
Before going any further, I should take notice of Aristotle's remarks in On Soul 1.1, for there we are told that emotions like anger and fright do not occur apart from bodily changes and that a complete scientific definition of such emotions is complex. It includes mention of some bodily change as well as a judgment and a desired goal. For example, being angry is by definition "a certain movement of a body of such and such a kind, or a part or capacity of it, (caused) by this thing for the sake of that" (403a26-7).

Here we have mention not only of the efficient cause --"(caused) by 43 this thing": i.e., on account of an apparent slight - and the final cause: "for the sake of that": i.e., for revenge-but also the material cause. In the case of anger, this third kind of cause is a certain movement of a body or more precisely, "a boiling of the blood and hot stuff around the heart" (403a31-b1). ${ }^{44}$ Beginning as we have from the Philebus, this emphasis on bodily factors is important. For in the Platonic dialogue, Socrates assigns emotions like anger and fright to the class of pains and pleasures that belong to the soul itself. In the context of the dialogue, the assignation is useful, for it helps to mark off these passions from others whose primary cause is bodily: a diseased state of the body or a depletion needing replenishment. But it can also give a misleading impression of emotional response. For when people become angry or frightened, the body too plays a role: it must be predisposed to the emotion, and the bodily changes that occur during the emotion have effects that are both public and private.

Concerning predisposition to emotional response, I offer two observations. First, Aristotle is careful to point out that the condition of the body may be a factor in explaining both strong and weak responses to a particular situation. He tells us that when the body is aroused, men are angered by trivia; but when the body is not aroused, they fail to exhibit exasperation. Similarly with fear, a man may be so disposed by his body that he has the experience of fright even though nothing frightening is occurring; or he may fail to be frightened despite the presence of dangers that are severe and clear (403a19-24). Second, the fact that men may be predisposed to extreme emotional response raises the question whether the predisposition can be altered in order to avoid unwanted responses. My suspicion is that Aristotle's answer would be bipartite. He would say that a temporary condition can be altered. An invasive medical procedure might remove accumulated blood or bile from a particular part of the body, or (less dangerously) a visit to the theater might result in an intense fright or a good laugh, so that the offending fluids are burned off and the person returned to a desirable condition. 45 But Aristotle would also say that a long-standing condition, whether innate or acquired, is not easily removed. Indeed, there may be no permanent cure. For an example I turn to his pupil Theophrastus, who in On Comedy told how the people of Tiryns tried to remedy their propensity to laughter. They asked the oracle at Delphi how they might be released from their condition and were told that they would be released if they performed a sacrifice without laughing. Fearing that a child might laugh, they attempted to remove all the children from the place of sacrifice; but one escaped notice and made an absurd remark that resulted in laughter. 46 In this way the people of Tiryns learned that their long-standing habit was incurable (ap. Athenaeus, The Sophists at Dinner 6.79 261D-E = 709.1.10 FHS\&G). What role this story played in the Theophrastean treatise On Comedy is uncertain. It may have been introduced to illustrate verbal humor or perhaps the possibilities of a comic plot revolving around a fixed disposition. But equally it could have served to underline the need for homeopathic therapy. Like the Tirynthians, many of us are given to excessive laughter; and since there is no permanent cure, we would do well to attend the comic theater and to obtain short-term relief through laughter.

43 Here the preposition "by" translates hypo. See Section I ad fin.

44 The Aristotelian definition of anger is accepted by Theophrastus. See On Sweat 36.230-1 F. The reference is to my edition of On Sweat (Leiden: Brill 2003) p. 46.

45 For intense fright, see Aristotle, Poetics 14 1453b5: the plot of a tragedy should produce shuddering in one who hears a tragedy read. By using the verb "to shudder" (phrittein), Aristotle indicates that the listener feels fear intensely and in doing so undergoes bodily change. See R. Janko, Aristotle, Poetics $I$, with the Tractatus Coislinianus, a Hypothetical Reconstruction of Poetics II, and the Fragments of the On Poets (Indianapolis: Hackett 1987) p. 105. For purgation through laughter, see the Tractatus Coislinianus 10-11 p. 64 Koster $=$ IV p. 24 Janko (Aristotle on Comedy: Towards a Reconstruction of Poetics II [Berkeley: University of California 1984]), where the definition of comedy ends with the following words: "through pleasure and laughter accomplishing the catharsis of such emotions."

46 The child confused two cognate Greek words: sphageion = "sacrificial bowl" and sphagion = "sacrificial victim." The child wanted to ask the adults whether they were frightened that he would overturn a bowl; but he mixed up the cognate words and asked whether they were worried that he would overturn the victim, which in this case is a bull. 
I have said that the bodily changes occurring during emotional response have effects that are both public and private. In speaking of "public" effects, I am thinking of superficial changes of the body like change in color and the appearance of sweat. For change in color, I cite Aristotle, who tells us that turning red is typical of shame, whereas turning pale is a mark of fright (Nicomachean Ethics 4.9 1128b13-14). For sweat, I turn to Theophrastus, who observes that sweat appears on the feet of men who are nervous, and does so because of an increase in bodily heat (On Sweat 36.226-30 F). 47 By "private" effects, I mean painful and pleasurable sensations. When an angry man says that he feels pain, he may be referring to a special mental feeling; but equally and in my judgment more probably, he may be referring to bodily discomfort, whose proximate cause is a change in the body, like the boiling of blood around the heart. In any case, there is no contradiction in saying that the painful sensations of anger are caused by bodily change and that anger is caused by the thought of being unfairly slighted. The latter comes first and causes a change in the body, which in turn produces an unpleasant sensation.

\section{Different Kinds of Laughter}

In the preceding section, I touched on laughter (gelôs) and mentioned the Tirynthians, who were unable to control their laughter. Now I want to focus on laughter, for its status as an emotion may be questioned. It may seem to be all noise and to lack the complexity of emotional response. In particular, there may be no necessary tie to judgment or belief conceived of as the cause of laughter. To be sure, we can always explain why a person laughs, but there are clear cases in which the cause is not a judgment. Laughter brought on by tickling is an example. Here the person who laughs is not responding to some situation that he assesses positively (or negatively); rather, the person laughs because he is being subjected to a particular kind of physical stimulus. A more dramatic case, which interested the Hippocratic doctors, is the laughter that follows upon a blow to the midriff. When the blow is caused by an enemy spear there is nothing funny in the situation, but the victim laughs before he dies (Epidemics $5.95,7.121)$. Still a different case is the person whose conversation is marked by laughter. I am thinking of the person who laughs between sentences and does so repeatedly in quite diverse circumstances. This is a puzzle case, for laughter can be a way of dealing with an uncomfortable situation. We can imagine someone who is thoroughly unsure of himself and expresses as well as hides his timidity (mild fear) by laughing. But there are other people who, for whatever reason, habitually laugh while engaged in conversation. They have acquired a mannerism that has no direct tie to what is normally thought of as emotional response.

Given the above cases, we may want to recognize different uses of the word "laughter." It may be used to refer to vocal noises that have the same or similar qualities but have quite different causes. It may also refer to finding something funny, i.e., to vocal responses that are caused by judgments (the person who laughs thinks that something is the case; he finds something funny) and are regularly accompanied by pleasant feelings. In this usage, "laughter" refers to a pleasant emotional response and not to a vocal noise (also called "laughter") that results from tickling or a blow to the midriff. Nor does it refer to an acquired mannerism that manifests itself in conversation and other verbal behavior. 48 If there is a difficulty here, it is that in classical Greek the word gelan is used not only with regard to laughing aloud, but also for cases of smiling that involve no noise whatsoever. ${ }^{49}$ Such double duty can, of course, be explained as ambiguous usage, but it is worth noting that some of the problems that arise when one considers diverse cases of laughter also arise when one considers smiling. Sometimes a smile signifies

47 The reference is to my edition of On Sweat (above, n.44) p. 46. Cf. pseudo-Aristotle, Problems 2.26.

48 When a man finds something funny and laughs, his judgment or more generally his thought is a central ingredient in his response. It is the efficient cause that is mentioned in the essential definition. (On essence and cause, see Section I.) While the involvement of thought as the efficient cause serves to mark off the laughter of finding something funny from laughter that has a physiological cause or is a mannerism, thought itself is a determinable (see Section VII ad fin.), so that it is possible to divide cases of finding something funny into several different kinds. See below on the division of the laughable into men, speech and deeds

${ }^{49}$ To be sure there is the verb meidian, which is used in regard to smiling (already in Homer, e.g., Iliad 1.595), but the word was used less frequently in the classical period, when gelan served for both laughing and smiling. See D. Arnould, Le rire et les larmes dans la littérature grecque d'Homère à Platon (Paris: les Belles Lettres 1990) $\mathrm{p}$. 138-42. Uses of the compound prosgelan are especially striking: Medea smiles at her children and Jason's new bride smiles at her reflection in a mirror (Euripides, Medea 1041, 1162). In Aristotle, fr. 183 Rose, prosgelan is used with reference to smiling at slaves. 
approval and is accompanied by feelings of pleasure. In such cases, we may want to speak of an emotion. But when a smile is a mannerism, it need not express approval and need not be accompanied by any feelings of pleasure. Indeed, the smile may be exhibited in most unpleasant situations, or all the time (like the smile on an archaic statue).

None of the above is likely to have caused problems for Aristotle. Whatever the ambiguities of the verb gelan, he, like all Greeks, will not have confused smiling with laughing aloud. Moreover, his interest in physiology and medical matters will have led him to isolate cases like the laughter that results from tickling or a blow to the midriff. Indeed, in the Parts of Animals, both tickling and a blow to the midriff are discussed (3.10 673a2-12), and the same is true of the Physical Problems (35.2 964b30-2, 35.6 965a14-17, 35.8 965a23-32). The latter work is, of course, post-Aristotelian, but nevertheless of some interest, for it makes clear that the physiological causes of laughter were part of a continuing discussion within the Peripatos.

What needs to be added, I think, is that Aristotle's remarks on comic laughter in the Poetics (as we now have it) are not a full expression of his understanding of laughter conceived of as a certain sort of noise that is caused by judgment and accompanied by pleasure. For in the Poetics, comedy is associated with worthless people, and the laughable is restricted to mistakes and deformities that are neither painful nor destructive (5 1449a32-5). That suggests a Hobbesian view of laughter ("sudden glory arising from some sudden conception of some eminency in ourselves by comparison with the inferiority of others, or with our own formerly" ${ }^{50}$ ), and while Aristotle certainly thinks that laughter can be occasioned by a recognition of one's own superiority, he does not think that all laughter has such a cause. Here a passage in the Rhetoric is instructive. I am thinking of 1.11 1371b35-1372a2, where Aristotle first divides the laughable into men, speech and deeds, and then refers to the Poetics, in which this division is said to have been set forth. The reference is to the lost second book of the Poetics, where Aristotle will have developed more fully his thoughts on comic laughter. He will have discussed laughter aroused by the presentation of men, i.e., the characterization of stage figures. Here he will have developed the idea of worthless people, or as he puts it elsewhere, men who are worse than those of the present day (2 1448a17-18). But he will also have taken account of laughter aroused by speech and deeds, e.g., word play and unexpected actions (cf. Tractatus Coislinianus 3 p. 51 Kaibel = V-VI p. 26-36 Janko, which may be closely related to the lost second book of the Poetics). Sometimes a connection will have been made with worthless people. For example, confusing two similar sounding words may be a mark of inferior intelligence, and the running slave through his action may exhibit a cowardly character. But Aristotle will not have insisted that every instance of word play and all forms of bizarre action are tied to inferiority even though they may arouse laughter when presented on the comic stage. Indeed, he will have recognized that word play can be enjoyed in itself (hence the anthology of clever remarks) and that the person who engages in, e.g., punning (on or off the stage) is exhibiting intelligence. In fact, it is partly the connection with intelligence that makes word play such an effective means of humiliating someone else. I cite Theophrastus who tells us that the cithara player Stratonicus used the proverb "No rotten fish is large" to insult the actor Simycas. By speaking the words separately, he indicated that the actor was a nobody, a rotten performer and a fish because of his lack of voice (Athenaeus, The Sophists at Dinner 8.40348A = 710 FHS\&G). In this way, Stratonicus exhibited his own command of language, put down Simycas and, we may be sure, aroused laughter in his audience.

In Section III, I called attention to the fact that some emotions are tied to particular goals, while others are not. Anger, for example, is goal directed in that an angry man seeks revenge. In contrast, pity is not closely tied to goal directed behavior, for when a person feels pity, there may be no way to remedy the situation. This difference means that laughter qua finding something funny (as against being struck by a spear etc.) is like pity and unlike anger in that there is no necessary connection with goal directed behavior. A person experiencing pity may break down in tears and sob aloud, but take no action, for the situation that has brought on the emotion cannot be remedied. Similarly the person who finds something funny may break down laughing and do nothing. He has no further goal that calls for planning or immediate action. Nevertheless, there is a difference between pity and laughter. When there is something that can be done to rectify a pitiful situation and a person is not moved to action, then we are apt to doubt that the person in question really feels pity. We may deem his tears insincere. In the case of laughter, there seems to be no parallel test of sincerity. A good laugh is compatible with leaving the situation as it is. And that is true even if it is possible to continue the merriment by telling a new joke or acting out some piece of bizarre behavior. Of course, there are people who guffaw loudly and do have a goal in mind, but their goal is not conceptually tied to laughter. I think especially of the flatter who is motivated

\footnotetext{
${ }^{50}$ Human Nature in The English works of Thomas Hobbes, ed. W. Molesworth (London 1840) vol. 4 p. 46.
} 
by self-interest. In Theophrastus' Characters, flattery is defined as shameful interaction that is beneficial to the flatterer (2.1). The sketch that follows depicts the flatterer laughing at frigid jokes. He guffaws and stuffs his coat in his mouth as if he is trying to control himself (2.4). But of course, he is in no danger of losing control. Moreover, he may not be enjoying himself except in so far as he imagines himself acquiring some advantage through his obsequious behavior. His laughter, then, is not laughter simpliciter. It is feigned laughter and as such it is not to be confused with finding something funny.

\section{An Analysis Emphasizing Similarity}

The definition of emotions given in Rhetoric 2 is oriented toward emotional appeal and therefore not intended as a general definition covering all the emotions felt by human beings. In a rhetorical context, that is understandable and even commendable, but we are left wondering whether Aristotle ever offered a truly general definition of emotional response. He may have done so in one or both of the lost works mentioned in Section II, but if he did, the definition is lost along with those works. My suspicion, however, is that Aristotle would have rejected a general definition in favor of an inclusive analysis that emphasizes similarity, for the phenomena in question have almost no common core and to the extent that they have one, it is determinable rather than determinate. 51

In developing this idea, it may be helpful to begin by looking at Book 8 of the Nicomachean Ethics, for here we have a rather clear example of the kind of analysis Aristotle could have offered in the case of emotion. I am thinking of the discussion of friendship. ${ }^{52}$ Aristotle recognizes three types: the friendship of virtuous men, that of pleasure seekers and that of men associated for the sake of utility. He is not in doubt that each of these types is properly called friendship, but he never offers a general definition applicable to all three. Instead, he focuses on the several ways in which the friendships resemble each other. He tells us that the three types exhibit common features: reciprocal affection, wishing well and awareness (8.1 1155b27-1156a5). These are the necessary marks of friendship, such that the absence of any one of them is sufficient to rule out friendship. But these features are not all there is to friendship. Each of the three types has its own goal: what is good, pleasant and useful (8.1 1155b18-21); and these goals serve not only to mark off the types but also to relate them through similarity based on analogy. For as the good is to virtuous friends, so the pleasant is to friends of pleasure and the useful to persons associated for the sake of utility. Finally, there are features shared by two of the types but not by all three. These features are the qualities of being pleasant and being useful. The friendship of virtuous men has both, while the friendship of pleasure seekers is pleasant but not useful, and vice versa for the friendship of men associated for utility. Accordingly, the friendships based on pleasure and utility resemble friendship based on virtue; and through that type of friendship, they are related indirectly to each other. ${ }^{53}$ In sum, friendship based on virtue is complete in that it has all the qualities looked for in a friendship; and for that reason, it is a kind of perfect or paradigm case. In comparison, the other types are incomplete; but they are still friendships, for they not only possess the necessary qualities but also exhibit similarity based on analogy and a relationship that is mediated through the perfect or complete friendship of virtuous men.

Returning now to the emotions, my suggestion is that Aristotle will have offered - or more cautiously, was capable of offering - a similar analysis. He could have pointed out that all emotions resemble each other in that they have thought as their efficient cause. As such, thought is not just a common feature; it is a necessary one, so that any passion resulting from a different cause is not an emotion. Aristotle could also take note of the goals that not only differentiate between emotions like anger and fright but also relate them through similarity based on analogy. For as the angry man has revenge as the goal for which acts, so too the frightened man has safety as his goal. In addition, Aristotle could observe that some emotions lack features that others have. Feelings of pain and pleasure come immediately to mind. Although anger and (on my interpretation) fear are tied to both pleasure and pain, hate is said to lack pain, and perhaps we should add pleasure. Similarly kindness, on one interpretation,

${ }^{51}$ In his Commentary on Aristotle's Nicomachean Ethics, Aspasius tells us the he was unable to find a definition of emotion among the older Peripatetics (CAG vol. 19.1 p. 44.20-1 Heylbut). His search may have been faulty, but more likely there was none to be found. See Fortenbaugh, "A Note on Aspasius, In EN 44.20-1," Proceedings of the World Conference on Aristotle, vol. 1 (Athens: Ministry of Culture and Sciences 1981) p. 175-8.

52 Aristotle's word for friendship is philia, the same word used in the Rhetoric for friendly feelings.

53 See Fortenbaugh, "Aristotle's Analysis of Friendship: Function and Analogy, Resemblance, and Focal Meaning," Phronesis 20 (1975) p. 56. 
may be thought to lack both pain and pleasure. ${ }^{54}$ Something similar can be said of goals. Anger and fright necessarily involve goals that lead to action. Angry men strive for revenge and frightened individuals seek safety. Hence, Aristotle tells us that anger is absent when revenge appears impossible (1.11 1370b13), and that fear requires some hope of safety, for fear makes men deliberate and no one deliberates concerning things considered hopeless $(2.5$ 1383a5-8). In contrast, there are other emotions that do not exhibit a necessary connection with goal directed behavior. Pity and shame are examples. Men can and often do feel pity when they perceive others suffering an evil for which there is no remedy; and they experience shame when they realize that they themselves have committed wrongs which are impossible to reverse. ${ }^{55}$ For our purposes the important point is that here, as with different types of friendship, we have the possibility of mediating a relationship. Kindness involves goal directed action, but it lacks, again on one interpretation, a close connection with feelings of pleasure or pain. In contrast, pity is marked by feelings of pain, but there is no necessary tie to goal directed behavior. Nevertheless, both emotions resemble central cases like anger and fright; and through these central cases, they are related to each other.

A difference between the analysis of types of friendship and the proposed analysis of emotions is the number of common characteristics. In the case of friendship, there are four characteristics possessed by each of the three types: namely, being goal oriented (a similarity established by analogy), reciprocal affection, wishing well and awareness (all necessary if friendship is to exist). In the case of emotions, the number is less. Goal directed behavior is characteristic of many but not all emotions, and the same is true of pain and pleasure. What is characteristic of all emotions is a single feature: namely, thought as the efficient cause. But having said that, let me emphasize that thought here is a determinable, much like wishing well in the case of friendships. When pleasure seekers and persons associated on the basis of utility wish each other well, the wish is self-interested and dependent upon the attainment of some pleasure or advantage. In the case of virtuous men, wishing well is very different; instead of self-interest, there is concern for the moral goodness of the parties involved. 56 Similarly in regard to emotions, no one thought is the efficient cause. In the case of anger, it is the thought of an unjustified slight; and in the case of fear, it is the thought of imminent danger. That suffices to mark a distinction between the two emotions, but these thoughts are not sufficient for the occurrence of anger and fright. There must also be action directed toward the appropriate goal and feelings of pain and pleasure. In the case of other emotions like pity and kindness, one or the other of these additional features may be missing, but there is always thought in a determinate form. 57

\section{Difference in Degree}

In Sections. V and VI, I had occasion to mention Theophrastus. I now want to call attention to his treatment of anger (orgê) and two closely related emotions: namely, faultfinding and rage (mempsis and thymos). I begin with anger, which Theophrastus, following Aristotle, regarded as a complex phenomenon. A fragment preserved by Stobaeus and another translated into Latin by Seneca make clear that Theophrastus viewed anger as a desire for revenge on account of injustice (Stobaeus, Anthology 3.19.12 Hense $=526.4$ FHS\&G and Seneca, On Anger $1.12 .3=446.1$ FHS\&G). A report by Marcus Aurelius tells us that Theophrastus recognized the involvement of pain in anger (Meditations $2.10=$

\footnotetext{
54 See above, Section III. A further example is laughter qua finding something funny. Here we have a response involving pleasure, but there is no necessary tie to pain. When a person laughs at, e.g., word play, there may be no feelings of pain. Of course, someone who envied the actor Simycas and heard Stratonicus humiliate him with the proverb "No rotten fish is large" (see Section VI) will have experienced the pain of envy before experiencing the pleasure of laughter. But the pain is not part of finding something funny. Rather, it is part of the envy, which "prepares the way" (cf. Rhetoric $2.21379 \mathrm{a} 21-2$ ) for laughter, while remaining a distinct emotion. See Above, Section IV.

55 Aristotle recognizes that pity is aroused by death, old age and ugliness (Rhet. $2.81386 \mathrm{a} 8,11)$, all of which are irremediable. In defining shame, he mentions painful sensations but omits any reference to action (Rhet. 2.6 $1383 \mathrm{~b} 12-14)$, for no action is necessarily involved in experiencing the emotion. We may call these emotions "nonpractical". in contrast to "practical" emotions like anger and fear. For fuller discussion, see Fortenbaugh (above, n. 3) p. 79-83. A further example of a non-practical emotion is the laughter of finding something funny. We often laugh with no goal in mind. See Section VI.

$56 \mathrm{Cf}$. Nicomachean Ethics 8.3 1156a9-14.

57 On the thought involved in finding something funny (it is determinable), see above, Section VI with note 48.
} 
441.3-4); this same text and another found in Simplicius inform us that Theophrastus did not ignore the bodily changes that accompany anger (On Aristotle's Physics 965.1 Diels = 271.3 FHS\&G). In sum, Theophrastus analyzed anger in terms of thought, goal directed behavior, feelings and bodily change.

What is new in Theophrastus is the introduction of difference in degree in order to distinguish between closely related emotions. Our source is Simplicius, who cites the Theophrastean work $O n$ Emotions and tells us that according to Theophrastus faultfinding, anger and rage differ in respect to the more and less (to mallon kai hêtton) and are not identical in kind (On Aristotle's Categories 253.7-8 = 438.6-8 FHS\&G). To this report, Simplicius adds a short list of other closely related emotionsfriendliness and goodwill, savagery, bestiality and anger, appetite and lust-and then observes that in general the more shameful emotions, when intensified, change into another kind $(253.8-13=438.8-12)$. It is not entirely clear whether the additional list of related emotions is taken from Theophrastus. Nor is it clear whether Theophrastus regarded difference of degree as merely compatible with or actually determinant of difference in kind. My inclination is to believe that the list is Theophrastean in origin and that Theophrastus did introduce the more and less in order to establish difference in kind. I offer three reasons in support of my belief. First, the list follows on faultfinding, anger and rage without noticeable interruption. Second, the mention of appetite and lust (epithymia and erôs) within the list invites comparison with Theophrastus' definition of lust. That definition is preserved by Stobaeus and runs as follows: "Lust is an excess of an unreasoning appetite, whose coming is swift and parting slow" (Anthology $4.20 .64=557.1-2$ FHS\&G). The definition fits neatly with Simplicius' observation concerning the more shameful emotions which, when intensified, become different in kind. It also supports the idea that difference in degree--here represented by excess, swift and slow-may be determinant of difference in kind and therefore mentioned in the essential definition. Third, there are parallels in Theophrastus' botanical works. I cite Research on Plants: in the introduction, Theophrastus makes special mention of the more and the less (1.1.6); and in the subsequent discussion of related kinds of plants, e.g. the date palm and doum-palm, he introduces difference in degree in order to distinguish between kinds. 58

No text reports the details of Theophrastus' analysis of faultfinding, anger and rage; but if the preceding remarks are correct, it seems likely that he applied difference in degree to one or more of the features involved in anger. He may have said that anger is caused by a greater injustice than faultfinding, involves a stronger desire for revenge, greater bodily disturbance and more pain. In contrast, anger falls short of rage in regard to the perceived injustice, desire for revenge, disturbance and pain. That is the simplest case: difference of degree applied to all features. But it is not the only possibility. At least in regard to faultfinding, it is easy to imagine an analysis in which a feature is said to be absent, either occasionally or always. Some faultfinders may have a weak desire for revenge, but do they all have such a desire? To be sure they all voice a complaint, but it is not clear that they always aim to hurt another person. Similarly with pain, many or most faultfinders may feel some minor discomfort, but it seems reasonable to believe that some faultfinders simply express annoyance without feeling anything that can reasonably be called pain. In this regard, a passage in Aristotle's Eudemian Ethics may be instructive. I am thinking of the second book, where Aristotle calls emotions "such things as rage, fright, shame, appetite and generally things that are in themselves accompanied for the most part by sensory pleasure and pain" (2.2 1220b12-14). If I understand Aristotle, he introduces the qualifier "sensory" (aisthêtikê), because he is referring to pleasant and painful sensations that are caused by bodily changes; and he says "for the most part" (hôs epi to polu) because he thinks that these sensations are not always present. On one interpretation, he means that there are whole kinds of emotion that are marked by an absence of sensation. ${ }^{59}$ Hate is a case in point and faultfinding might be another. On a different interpretation, one that I find more plausible, 60 Aristotle is taking account of individual occurrences in which sensations are not experienced. Faultfinding, for example, is normally accompanied by pain, but occasionally the bodily disturbance is so weak that no painful sensation is experienced. Here again it may be helpful to cite the introduction to Research on Plants. For Theophrastus states clearly that a part that belongs to the nature of a plant can be absent in a particular specimen; and when it is absent, there is always an explanation

58 See Research on Plants 2.6.6-11; and for more detailed discussion, see Fortenbaugh, "Theophrastus on Emotion", in Theophrastus of Eresus: On His Life and Work, ed. W. Fortenbaugh, P. Huby and A. Long = Rutgers University Studies in Classical Humanities II (Transaction: New Brunswick1985) p. 213-14.

59 S. Leighton, “Eudemian Ethics 1220b11-13," Classical Quarterly 34 (1984) p. 135-8.

${ }^{60}$ Fortenbaugh (above, n. 58) p. 217-19, in agreement with M. Woods, Aristotle's Eudemian Ethics; Books $I$. II, and VIII (Oxford: Clarendon 1982) p. 110. 
like disease or old age or mutilation (1.1.2). Similarly with emotions, Theophrastus may well have said that pain is a normal feature that in particular cases and for a particular reason may fail to be present. And if he did say that, he may have gone on to cite faultfinding as an example. But whatever the truth concerning this emotion, it does seem likely that Theophrastus would recognize that an adequate analysis of related kinds will consider absences and well as differences in degree.

\section{Emotion, Good Character and Moral Virtue}

In Section I of this paper, I discussed Aristotle's explanation of the involvement of thought in emotional response, and in Section VII, I pointed out that the thought involved in emotion is determinable, i.e., thought in a determinate form. I now want to emphasize that for many emotions the thought in question has both a factual and an evaluative component. Take anger as an example. When a man is angry, he believes that someone has done something, perhaps made a hand gesture or passed by in silence, and he deems this behavior unjustified. Here there is not only factual apprehension, seeing a gesture or noticing silence, but also evaluation. The angry man assesses another person's action negatively and expresses this assessment in seeking revenge. Aristotle understands that; and in defining anger, he chooses to emphasize evaluation. He first mentions an apparent "slight " (oligôria) as the cause of anger and then adds "the slight being unjustified" (tou oligôrein mê prosêkontos, Rhet. 2.2 1378a32-3, cf. $2.21379 \mathrm{~b} 11-12) .61$ Without that assessment, i.e., without deeming the slight unjustified, there would be no anger: For example, when a man thinks that he himself has done wrong and is being punished justly, a painful emotion is possible, but it will not be anger (cf. $2.31380 \mathrm{~b} 16-18$ ).

Similarly in regard to fear, it is not enough to observe that bodily harm is imminent. The frightened man must also assess the harm negatively and manifest this assessment in seeking safety. As Aristotle puts it, the frightened man is necessarily in preparation $(2.51382 \mathrm{~b} 3-4)$. The involvement of evaluation in other emotions is, I think, clear enough. 62 It may, however, be helpful to add two qualifying remarks. First, although the frightened man, like the angry man, expresses his negative assessment in goal directed behavior, there are emotions in which evaluation need not lead to action. Indignation and pity are examples. Both emotions involve a negative evaluation-"The good fortune of that person is unmerited"; "The suffering of another is unmerited" $(2.81385 \mathrm{~b} 13-14,2.91386 \mathrm{~b} 9-14)$-but neither need be expressed in action. Rectification may be quite impossible, so that any action would be no more than an expression of displeasure. Second, not all emotions involve evaluation. A clear example is finding something funny. ${ }^{63}$ The cause is always a thought, but there need not be an assessment of the situation as merited or unmerited, just or unjust. Rather people often laugh at, e.g., the unexpected or word play such as a pun or clever repetition. 64 That will have been recognized by Aristotle, Theophrastus and other Peripatetics, who discussed the matter in works on comedy and more generally on the ridiculous. 65

The involvement of evaluation in emotions like anger, fright, indignation and pity means that these emotions can express character. In the Rhetoric, Aristotle makes the point explicitly when he says that both pity and indignation belong to good character (êthos chrêston), for men ought to feel pity for those whose suffering is unmerited, and to feel indignation when success is unmerited (2.9 1386 b12-14). Aristotle goes on to say that indignation is attributed to the gods (1386b15-16), but he never refers

${ }^{61}$ I have translated oligôria with "slight" not only because it is close to the root meaning of oligôria, but also because one can easily speak of a justified as well as an unjustified (deserved as well as undeserved) slight. That would not be true if oligôria were translated with, e.g., "outrage" as I have occasionally done elsewhere (e.g. Aristotle on Emotion [above, n. 3] p. 11).

62 For fuller remarks on evaluation and its application to Aristotle's analysis of emotions, see Fortenbaugh, "Aristotle: Emotion and Moral Virtue", Arethusa 2 (1969) p. 164-7. In the recent literature, see, e.g., A. Nehamas, "Pity and Fear in the Rhetoric and the Poetics," in Aristotle's Rhetoric: Philosophical Essays, ed. by D. Furley and A Nehamas (Princeton: University Press 1994) p. 264.

63 I speak of "finding something funny" instead of "laughter," because the former seems to me more restrictive, suggesting a response caused by thought and therefore ruling out cases of laughter caused by tickling and the like. But most of the time laughter is caused by thought and therefore part of an emotional response. See above, Section VI.

64 See Section VI and note 45 in Section V.

65 See the Tractatus Coislinianus 13-30 p. 63-4 Koster = V-VI p. 24-36 Janko (1984 [above n. 45]), where the causes of laughter are divided into language and situations (lexis and pragmata). 
indignation or pity to moral virtue (êthikê aretê). That is because he thinks of moral virtue as a disposition to act and therefore as a disposition tied to emotions that regularly manifest themselves in action. ${ }^{6}$ Good temper (praotês) is the moral virtue related to anger, and the man of good temper is one who both assesses the situation correctly - he is not mistaken in perceiving an unjustified slight-and seeks revenge in an appropriate manner. Similarly, courage (andreia) is the moral virtue related to fear, and the courageous man is one who assesses danger correctly and confronts it as the situation demands. 67

These appropriate responses are made possible by moral training during youth (EN2.3 1104b11-13). For example, a young man is taught to respect other people according to their merit. He learns that respectful treatment is a fine thing and disrespectful treatment something bad. In this way, he acquires moral principles that are action guiding. When disrespectful treatment occurs, he recognizes an unjustified slight; and should the slight be directed toward himself or those close to him, he exhibits his virtue by becoming angry and seeking appropriate revenge. As Aristotle says, "Virtue when outraged always chooses to act" (Rhet. $2.51382 \mathrm{a} 35-\mathrm{b} 2)$; and as Theophrastus puts it, "Good men are angered on account of wrongs done to their own (close friends and relatives). ... It cannot happen that a good man is not angered by evil." (ap. Seneca, On Anger 1.12.3, 14.1 = 446.1,6-7 FHS\&G).

Similarly with fear, a young man is taught to despise danger and to express this evaluation in action (EN $2.21104 \mathrm{~b} 1-3)$. He learns to remain steadfast, because doing so is fine or noble $(1115 \mathrm{~b} 12,23$, $11116 \mathrm{a} 11, \mathrm{~b} 31)$. Here, too, education has conveyed principles that govern action. 68 This education is not an eradication of fear. On the contrary, the courageous man will feel fear, but his fear will be moderate and appropriate to the occasion. Generally he is not frightened out of his senses (3.7 1115b11); and as a result, he is able to reflect on his situation and to deliberate about means to meet the danger confronting him. ${ }^{69}$ If reflection shows that the situation is not what it appeared to be, his response will be altered; and if deliberation shows that one way to meet the danger is better than another, the better way will be chosen.

These reflections and deliberations are not in themselves emotional responses. Rather they are acts of reasoning that follow on emotional response. In the absence of moral virtue, they might not occur, for strong emotions interfere with reasoning; 70 but it is not moral virtue that guarantees the correctness of the reasoning itself. That is the work of practical wisdom (phronêsis). What moral virtue does do is guarantee the appropriateness of emotional response. Of course, an initial response may turn out to be second best or worse. The facts of the situation are sometimes different from what they appear to be. Nevertheless, the morally virtuous man will always respond in accordance with his principles, choosing, e.g., to remain at his post rather than flee, for courageous action is something noble and a good in itself. Aristotle makes the point in regard to sudden dangers (3.8 1117a17-20). When the situation allows time for deliberation, a person lacking courage may remain in his post, because he has considered his options and come to realize that the apparent danger can be safely met. But when the immediacy of the situation

${ }^{66}$ Moral virtue is repeatedly said to be a disposition concerning emotions and actions (EN 2.3 1104b13-14, 2.6 $1106 \mathrm{~b} 24-5,3.11109 \mathrm{~b} 30$ ).

${ }^{67}$ I shall soon introduce a qualification. Although the good-tempered man and the courageous man normally assess the situation correctly, there are occasions when the situation is not what it appears to be. In such cases, reflection may lead one to alter or to abandon an initial emotional response.

68 While principles may be learned from parents and tutors who give general directives concerning virtuous action, they may also be acquired through song and poetry and literature in general. For example, to teach a youth the importance of facing danger bravely, he might be asked to read or listen to an elegy of Tyrtaeus, in which the poet describes the death of a young soldier as something fine or noble (fr. 10.30). See Fortenbaugh, "Un modo di affrontare la distinzione fra virtù etica e saggezza in Aristotele", Museum Patavinum 5 (1987) p. 251; reprinted in English as "Aristotle's Distinction Between Moral Virtue and Practical Wisdom", in Essays in Ancient Greek Philosophy IV, Aristotle's Ethics, ed. by J. Anton and A. Preus (Albany: State University of NY Press 1991) p. 103.

69 I use two different verbs, "to reflect" and "to deliberate," in order to emphasize that a man may ponder both the appropriateness of his response to a particular situation (Is there a real danger here? Is my response too weak or too strong?) and the means to realize a desired goal (Is this or that the better way to achieve safety?). Nevertheless, I want to be clear that my usage is arbitrary: "to deliberate" can be used for both cases, as can bouleuein in Greek.

$70 \mathrm{Cf}$. Theophrastus, ap. Stobaeus, Anthology 3.19.12 = 526.2-4 FHS\&G, where we are told that strong anger prevents a man from acting with forethought; in a rage, he is, as it were, drunken with contentiousness and subject to impulse. 
rules out deliberation, ${ }^{71}$ character is revealed in emotional response. The coward flees, and the courageous man stands his ground, because he believes it noble to do so.

If the above is clear, it should also be clear why Aristotle connects moral virtue with the goal of action and practical wisdom with the means to accomplish the goal (6.13 1145a4-6). He is thinking in terms of emotion and reasoning: i.e., goal directed emotional responses like anger and fright, and the deliberations that are occasioned by these emotions and determine how best to realize the goals involved in them. Aristotle's statement only becomes difficult when we dissociate emotion from thought or so emphasize the connection of emotion with pleasure and pain, that we obscure other elements: namely, the evaluations and goals that are part of emotions like anger and fright. 72 We need to keep in mind that emotional responses are not locked into the present: revenge and safety are typically goals that can only be realized at some future time: And we need to remember that the moral education of young people conveys principles concerning what is fine or noble: general directives which not only provide an orientation for one's life but also determine how one responds to particular situations.

In conclusion, I want to be clear that the early Peripatetics recognized the limitations of moral education. Acquiring principles and being trained to respond in accordance with these principles are, of course, important first steps toward moral perfection, but real excellence involves an independence that is not conveyed by training during youth. That training produces obedience to one's superiors: parents, rulers and the laws of the state. What is needed for perfection is an understanding of why these authorities offer certain directives and not others, and how the directives relate to each other and to human happiness. Such understanding is not easy to come by. It requires sound training in youth, considerable experience over many years and careful reflection on law and custom. Few will complete the process, but those who do will be transformed into autonomous moral agents. Aristotle makes the point in the Politics, when he describes the virtue of the good man - one who has acquired practical wisdom as well as moral virtue - as "fit to rule" (3.4 1277a28) and "different in kind" (1277b17). So too Theophrastus tells us that practical wisdom gives the just man "his special form" (ap. Stobaeus, Anthology 2.7.20 = 449A.35). For both Peripatetics, the addition of wisdom to moral virtue works the same effect. The individual is freed from strict obedience to the directives of authority, because he can appreciate the limitations of such directives and recognize situations that call for exceptional behavior. 73

71 In offering a résumé of my earlier work, Smith p. 62 attributes to me the following view: "In many situations, indeed in all where action is immediately required, wisdom is superfluous." This statement seems to me misleading, for to say that "wisdom is superfluous" suggests that wisdom might be present: i.e., the deliberations of. practical wisdom, might occur. But the sudden situation rules out any exercise of wisdom; there is only emotional response.

72 I am responding here to A. Smith "Character and Intellect in Aristotle's Ethics," Phronesis 41 (1996) p. 703. who contrasts being motivated by pleasure and pain with following reason. In many contexts, the contrast is unobjectionable; but it distorts the framework within which Aristotle sets out his view of moral virtue.

${ }^{73}$ For fuller discussion see Fortenbaugh, "Theophrastus, fr. 534 FHS\&G: On Assisting a Friend Contrary to the Law," Synthesis Philosophica 10 (1990) p. 463-5. Smith (above n. 72) p. 64 misrepresents my view when he describes it as one that "implies that wisdom is ethically wholly otiose." 